\title{
Pembuatan Game Edukasi Pemadam Kebakaran
}

\author{
Muhammad Azmi Abdussalam \\ ${ }^{a}$ Politeknik Negeri Media Kreatif
}

\section{INFORMASI ARTIKEL}

Sejarah Artikel:

Diterima Redaksi: 2 Juni 2021

Diterbitkan Online: 31 Juli 2021

\section{KATA KUNCI}

Game

Game Edukasi

Pemadam Kebakaran

KORESPONDENSI

Email : azmi.abdussalam@gmail.com

\section{A B S T R A C T}

Game dapat dijadikan sebagai media edukasi untuk memberikan pengetahuan dan pemahaman terhadap suatu objek. Edukasi melalui media game diharapkan akan memberikan dampak menyenangkan bagi pemain yang dilakukan dalam suasana belajar. Salah satu objek yang dapat diedukasi ialah mengenai pemadam kebakaran. Pembuatan game ini dirumuskan dalam rumusan masalah bagaimana pembuatan game sebagai media edukasi pemadam kebakaran. Tujuan penulisan ialah untuk mengetahui pembuatan game sebagai media edukasi pemadam kebakaran. Pembuatan game ini terdiri dari tahap praproduksi, tahap produksi, dan tahap pascaproduksi. Melalui game mengenai pemadam kebakaran ini pemain dapat memiliki pengetahuan, pemahaman, dan gambaran keterampilan dalam menangani bencana kebakaran. Game ini juga menjadi media edukasi alternatif dalam pendidikan kebencanaan khususnya mengenai bencana kebakaran.

\section{PENDAHULUAN}

Game bagi manusia tentu merupakan suatu hal yang tidak dapat dipisahkan. Manusia akan menciptakan sebuah game dan terkadang berhubungan dengan pencapaian eksistensi dirinya. Game yang dimainkan tentunya beragam baik dari tujuan permainan maupun media yang digunakan. Salah satu tujuan dimainkannya game ialah sebagai sarana edukasi penyampaian pesan atau sebuah nilai.

Ernest Adams (2009) mendefinisikan game sebagai $a$ type of play activity, conducted in the context of a pretended reality, in which the participants try to achieve at least one arbitrary, nontrivial goal by acting in accordance with rules. Sedangkan Chris Crawford (2003) menyampaikan bahwa game merupakan salah satu media yang digunakan untuk menyampaikan suatu pesan kepada orang umum dalam bentuk permainan yang dapat menghibur. Ernest Adams dan Joris Dormans (2012) menyimpulkan bahwa game refer to rules, determine what players can do and how the game will react.

Ernest Adams dan Joris Dormans (2012) membagi genre game kedalam beberapa klasifikasi yakni action, strategy, role-playing, sports, vehicle simulation, management simulation, adventure, puzzle, dan social games. Menurut mereka, genre game tersebut dapat diimplementasikan dalam tipe mechanics yang dapat dijumpai dalam suatu game mencakup physics, internal economy, progression mechanisms, tactical maneuvering, dan social interaction.

Selain sebagai sebuah hiburan dan permainan, game juga dapat dijadikan sebagai media edukasi terutama untuk mengembangkan pengetahuan, pemahaman, dan keterampilan terkait sebuah objek yang diedukasi. Melalui permainan yang dimainkan proses edukasi dapat dinilai lebih mudah sehingga pemain akan mendapatkan pesan dari apa yang dimuat dalam game tersebut.

Maria Virvou (2005) menyebutkan bahwa dengan teknologi game dapat digunakan untuk membuat perangkat lunak sebagai media pembelajaran yang lebih memotivasi dan menarik, sehingga proses pembelajaran lebih menyenangkan. Edvin Batuwael, dkk. (2016) juga menyebutkan bahwa game berjenis edukasi ini bertujuan untuk memancing minat belajar peserta didik terhadap materi pelajaran secara menyenangkan, sehingga dengan perasaan senang inilah yang diharapkan mereka dapat lebih mudah memahami materi pelajaran yang disajikan.

Salah satu objek yang dapat diedukasi ialah mengenai alat pemadam kebakaran. Edukasi mengenai alat pemadam kebaran dinilai penting karena pengenalan mengenai objek tersebut harus dilakukan sejak dini apalagi dalam konteks masyarakat yang kerap mengalami bencana kebakaran. 
Edukasi yang dilakukan selain mengenalkan alat pemadam kebakaran juga untuk memberikan gambaran bagaimana kebakaran diatasi.

Dari pemaparan di atas, penulis tertarik untuk membuat game 2D untuk mengenalkan alat pemadam kebakaran dan proses pemadamannya dengan genre game adventure dimana pemain nantinya akan melewati berbagai rintangan dalam setiap level dan akan memperoleh skor tertentu.

Rumusan masalah dalam pembuatan game ini adalah bagaimana pembuatan game sebagai media edukasi pemadam kebakaran?. Tujuan penulisan ialah untuk mengetahui pembuatan game sebagai media edukasi pemadam kebakaran.

Pembuatan game ini dibatasi pada hal-hal sebagai berikut: pembuatan game berupa 2D dan dibuat secara interaktif agar menarik dan mudah dipahami pengguna, konten yang dibuat hanya membahas media tentang cara memadamkan kebakaran oleh pemadam kebakaran, serta asset game hanya memuat alat pemadam kebakaran.

\section{PEMBAHASAN}

Sebelum membuat game ini, penulis menganalisis kebutuhan yang diperlukan serta menentukan target dan sasaran yang ingin dicapai. Melalui telaahan yang dilakukan, diketahui bahwa metode penyuluhan dan sosialisasi yang dilakukan Pos Pemadam Kebakaran Sektor X Srengseng Sawah masih menggunakan metode konvensional yaitu sosialisasi langsung kepada warga sekitar atau dengan mengajak anak sekolah (SD dan SMP) untuk belajar langsung di tempat.

Penulis juga mengidentifikasi kebutuhan yang diperlukan dalam pembuatan game ini yakni menggunakan software Adobe Illustrator serta memanfaatkan Spine Pro dan juga Construct 2.

Melalui curah pendapat dengan pihak-pihak terkait, penulis mencetuskan ide dan konsep pembuatan game 2D mengenai cara memadamkan kebakaran menggunakan alat pemadam kebakaran oleh pemadam kebakaran, dengan berbasis android ini sebagai media edukasi baru mengenai cara penanggulangan bencana kebakaran. Game 2D ini mengajak pemain untuk bertindak sebagai petugas pemadam kebakaran dan berisikan informasi tentang bagaimana menanggulangi kebakaran berdasarkan klasifikasi kelas alat pemadam kebakaran ringan.

Tampilan grafis 2D menggambarkan petugas pemadam kebakaran memadamkan api dengan situasi dan kondisi tertentu sesuai dengan penggunaan alat pemadam api ringan dengan klasifikasi tertentu yang berguna untuk kondisi tertentu sesuai standar yang berlaku. Game dirancang dengan tiga level yang mempunyai situasi dan kondisi berbeda. Setiap level diberikan edukasi terhadap jenis alat pemadam kebakaran ringan yang digunakan dan didesain dengan ilustrasi yang menarik sehingga pemain dapat mudah dalam bermain sambil belajar.
Pembuatan game ini melalui tiga tahapan yakni tahap praproduksi, tahap produksi, dan tahap pascaproduksi. Tahap praproduksi mencakup brainstorming konsep dimana penulis mencari solusi untuk masalah yang ditemukan dengan menggunakan sebuah teknologi terbaru, pengumpulan data yang dilakukan melalui wawancara

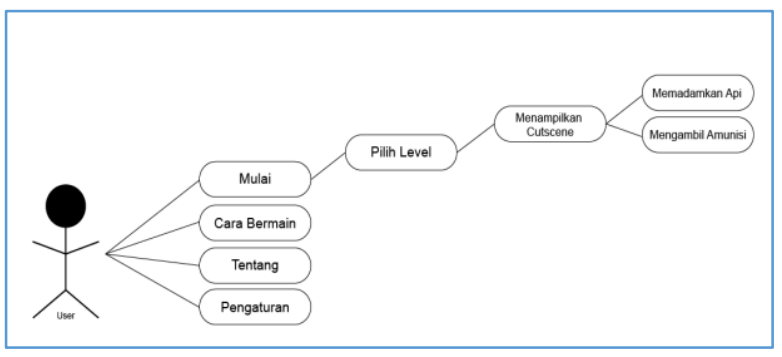

Gambar 1. Use Case Diagram

Sumber: penulis

untuk mendapatkan situasi yang diperlukan dalam pembuatan game ini dan studi kepustakaan untuk mendapatkan liteartur-literatur terkait, serta melakukan sketsa konsep game dengan membuat konsep visual secara manual agar konsep digital nantinya akan lebih matang.

Tahap produksi sebagai pewujudan ide dan konsep pembuatan game ini. Tahap awal yang dilakukan melalui pembuatan ilustrasi asset adalah pembuatan desain karakter dan part pendukung sebagai dasar pembuatan game. Tahap yang dilakukan setelah pembuatan asset game ialah rigging asset karakter agar dapat bergerak mengikuti arahan pemain.

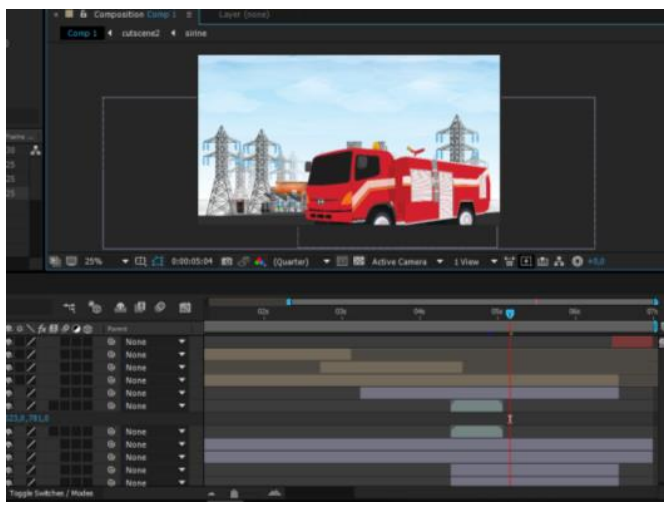

Gambar 2 Pembuatan Asset Game Sumber: penulis

Proses produksi juga membuat cutscene level dengan pembuatan mini story dalam bentuk video. Pada tahap ini segala unsur tampilan video dibuat, imulai dari memasukkan objek-objek yang dibutuhkan, menaruhnya ke dalam timeline dibagian bawah pada tampilan Adobe After Effects dan memberi efek/transisi yang diperlukan. Cutscene yang dibuat dilakukan pada setiap level. 


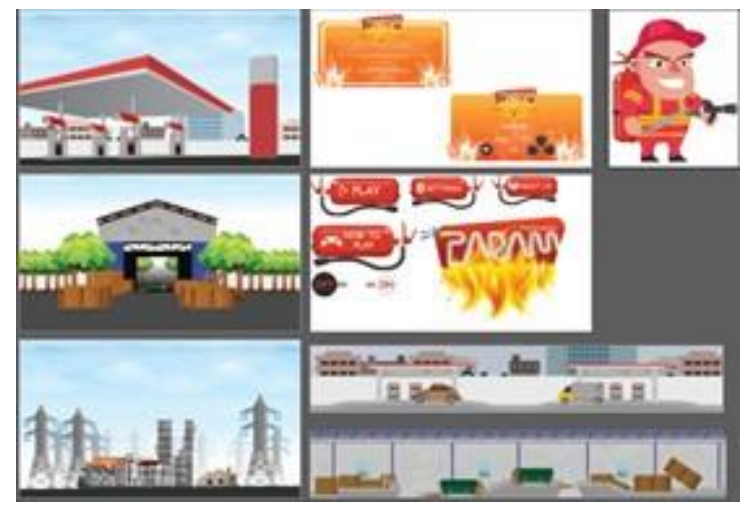

Gambar 3 Cutscene Game

Sumber: penulis

Pembuatan level game dimana penulis memasukkan beberapa objek yang akan muncul pada game yaitu berupa karakter game dan part pendukung seperti amunisi, rintangan dan meng-coding karakter dan part pendukung lainnya yang sudah ditempatkan pada game level agar bisa berjalan sesuai dengan konsep yang dibuat.

Build game dilakukan dalam tahap produksi dimana game yang sudah di-coding kemudian di-export menjadi format .apk agar bisa dijalankan pada smartphone berbasis android.

Selanjutnya pembuatan game ini ialah tahap pascaproduksi untuk melakukan testing dengan menggunakan beberapa smartphone android yang berbeda. Testing bertujuan untuk memastikan apakah aplikasi sudah berjalan sesuai fungsinya atau masih ada kesalahan lainnya. Apabila masih terdapat kesalahan lainnya, penulis segera memperbaikinya kembali hingga akhirnya aplikasi siap untuk digunakan. Berikutnya ialah mempublikasikan game dengan memanfaatkan media yang ada. Selain untuk menguji kegunaan game, tahap testing juga untuk mengetahui bagaimana pengalaman pengguna saat menggunakan game yang sudah dibuat.

Pembuatan game juga memuat perancangan user interface agar game yang dibuat dapat sesuai dengan visibility dan usability pengguna. User interface yang dirancang memuat struktur menu, halaman menu utama, halaman mulai, halaman cara bermain, halaman tentang, dan halaman pengaturan.

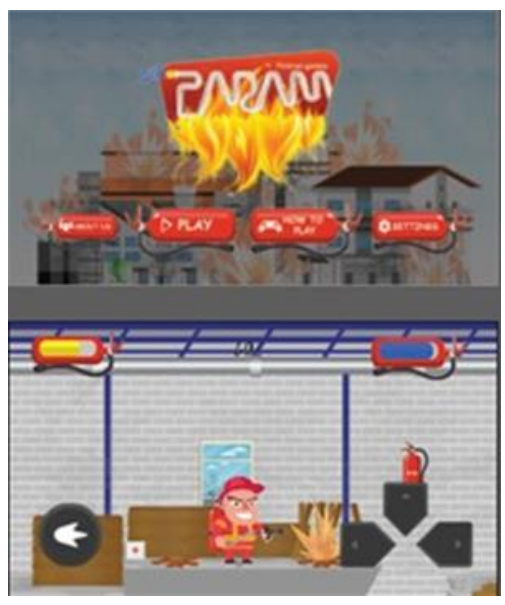

Gambar 4 User Interface Game Sumber: penulis

Setelah tampilan User Interface selesai dibuat, segala objek harus di export dan ketika di export harus dipisahkan objek yang akan memiliki action/fungsi dengan yang tidak, agar memudahkan pada saat proses perancangan game edukasi ini. Format yang dibutuhkan untuk user interface adalah .jpeg pada objek yang memiliki bentuk dasar persegi/persegi panjang dan .png yang tidak memiliki bentuk dasar persegi/persegi panjang.

\section{PENUTUP}

\section{Kesimpulan}

Game ini dibuat sebagai media edukasi pengenalan alat pemadam kebakaran sekaligus memperkenalkan cara pemakaiannya dalam kasus-kasus yang dibuat berdasarkan leveling game yang dibuat dalam tiga level. Pembuatan game ini terdiri dari tiga tahap yakni tahap praproduksi berupa curah pendapat dan pengumpulan data, tahap produksi yang meliputi pembuatan illustrasi asset, rigging karakter pembuatan cutscene level, pembuatan menu interface game, pembuatan game level, dan build game, serta tahap pascaproduksi meliputi testing dan publish game.

\section{Saran}

Saran bagi pembuatan media game serupa dimasa yang datang ialah penambahan data yang lebih luas mengenai alat pemadaman diluar dari asset game yang sudah ada, animasi dan environment yang lebih beragam lagi agar menambah pengalaman pemain untuk bisa menikmati game edukasi, peningkatan menjadi game 3D, menambahkan level, dan memperkaya obstacle pada setiap level sehingga lebih menantang pengguna. 


\section{DAFTAR PUSTAKA}

Adams, E. 2009. Fundamentals of Game Design, Second Edition. Berkeley, CA: Peachpit Press/New Riders.

Adams, E., dan Joris Dormans. 2012. Game Mechanics: Advanced Game Design. Berkeley, CA: New Riders.

Batuwael, E., dkk. 2016. Analisa dan Perancangan Game Edukasi Kebersihan Mulut pada Anak Umur 5-10 Tahun Berbasis Android. E-Journal Teknik Informatika, Vol 7, No 1, 1-6.

Crawford, C.. 2003. Chris Crawford on Game Design. Berkeley, CA: New Riders.

Virvou, M. 2005. Combining Software Games with Education: Evaluation of its Educational Effectiveness. Jurnal Evaluation of its Educational Effectives. Education technology \& Society, 8 (2), 54-65. 